Volume 3, No. 12021

P-ISSN: 2655-5166

E-ISSN: $2715-2103$

Homepage : http://journal.iaimsinjai.ac.id/indeks.php/retorika

\title{
Islam Liberal, Sejarah Perkembangannya, dan Kritik serta Saran Terhadap Pemikiran Islam Liberal
}

\author{
Ismail Latuapo ${ }^{1}$, Muliati Amin ${ }^{2}$ \\ ${ }^{1}$ Dakwah dan Komunikasi UIN Alaudin Makassar \\ ${ }^{2}$ Dosen UIN Alaudin Makassar \\ Email: ismail.latuapo@gmail.com
}

\begin{abstract}
Abstrak
Penulis berusaha dalam tulisan ini membahasa dan mengkaji mengenai pemikiran Islam Liberal dan kritikan tehadap pemikiran tersebut, agar umat Islam di Indonesia bisa menjauhi pemikiran yang sangat bertentangan dengan prinsipprinsip Islam ini. Dalam karya ini juga penulis menjelaskan sedikit menganai arti dari kata Islam dan Liberal karena dua kata ini ketika digabungkan sangatlah kontradiksi, yang mana Islam dalam arti tunduk dan patuh sedangkan Liberal memiliki arti bebas. Dalam sejarah perkembangan Liberalisme di Indonesia bermula pada tahun 1970 dan berkembang dengan tiga fase hingga munculah fatwa MUI tntang pelarangan pemikiran tersebut. Dan penulis menyinggung sedikit tentang hiruk pikuknya pemikiran Islam Liberal dan kritikas serta respon dari pada ormas-ormas yang baru muncul setelah masa reformasi hingga dua ormas terbesar dan tertua di Indonesia yaitu NU dan Muhammadiyah.
\end{abstract}

Kata Kunci : Islam, Liberal, Sejarah, Kritik 
Volume 3, No. 12021

P-ISSN: 2655-5166

E-ISSN: $2715-2103$

Homepage : http://journal.iaimsinjai.ac.id/indeks.php/retorika

\section{PENDAHULUAN}

Pemikiran liberalisasi Islam, yang sekarang kita kenal dengan sebutan Islam liberal dalam dunia pemikiran Islam pada masa ini, khusunya di negeri tercinta kita indonesia, telah menimbulkan begitu banyak kontrovesi dan perdebatan yang tidak ada habisnya. Ini disebabkan banyaknya gagasan dan ide yang mereka kemukakan sangat bertentangan dengan prinsip-prinsip dasar Islam. Di antara gagasan yang paling menonjol dari pemahaman Islam liberal adalah seperti menanamkan keragu-raguan terhadap keshahihan hadits nabi Muhammad sallahu alaihi wasallama, menanamkan keragu-raguan terhadap sebagian hadits dalam Shahih al-Bukhari dan Muslim, menanamkan keragu-raguan pada kodifikasi hadits nabi Muhammad sallahu alaihi wasallam, dan mengkritisi kredibilitas para sahabat radiallahu anhum dan para ulama. ${ }^{1}$

Pemikiran liberalisme merupakan suatu pemikiran yang berbahaya dimana telah tersebar di tanah air kita dan menjalar kepada anak-anak muda, terutama dikalangan kampus sering terkena penyakit liberalisme, dan yang mengusung pemikiran liberalisme di indonesia adalah tokoh-tokoh yang sangat terkenal di negara kita diantaranya tokoh-tokoh agama, rektor universitas. Ternyata pemikiran ini tidak di dukung oleh orang-orang sembarangan akan tetapi didukung oleh orang-orang yang sangat berpengaruh di NKRI ini.

Disamping itu pula Islam liberal juga menolak penerapan syariat Islam secara formal oleh negara. Dan mereka menolak dengan berbagai alasan, terkadang penolakan tersebut dibuat atas dasar budaya dengan mengatakan bahwa hukum Islam tidak mencerminkan nilai-nilai budaya masyarakat hari ini. ${ }^{2}$

Dalam kontesk keindonesiaan, kata liberal di pertemukan dengan kata Islam yang mana sebagai agama samawi, kedua kata tersebut dijadikan satu menjadi Islam liberal. Kata Islam liberal apabila kita teliti dan kita pahami maka perpaduan antara dua kata tersebut sangatlah rancu dan kontradiksi. Oleh karena itu pemahaman yang dibawakan oleh orang-orang yang berpaham Islam liberal

\footnotetext{
${ }^{1}$ Muhammad Hamid An-Nashir, Mengupas Hakikat Gerakan Modernisasi, liberalisme dan Westernisasi Ajaran islam, (Darul Haq : Jakarta, 2016), hlm. 61.

${ }^{2}$ Nirwan Syarifin, Kritik Terhadap Paham Liberalisasi Syariat Islam (Jakarta : Dewan Dakwah Islamiyah Indonesia, 2008), h,1-2.
} 
Volume 3, No. 12021

P-ISSN: 2655-5166

E-ISSN: 2715-2103

Homepage : http://journal.iaimsinjai.ac.id/indeks.php/retorika

sangatlah jauh dari ajaran islam itu sendiri. Dalam hal ini Nashruddin Syarif dalam buku menyatakan bahwa menyandingkan Islam dengan liberal sebanarnya merupakan sesuatu yang sangat problematik. "Islam" artinya tunduk, patuh, menyerahkan diri kepada Allah ta'ala. Sementara liberal artinya bebas dari setiap otoritas. Jadi, jika Islam menuntut adanya kepatuhan kepada aturan ilahi, maka liberal menghendaki adanya kebebasan dari segala macam aturan ilahi. Itu artinya tidak mungkin Islam liberal. Islam ya Islam bukan liberal. Hanya dikarenakan istilah Islam liberal sudah dibakukan oleh sebagian orang untuk menunjuk satu kelompok liberal dalam komunitas pemikir Islam. ${ }^{3}$

Berdasarkan fenomena yang terjadi dapat kita pahami liberalisme adalah merupakan pemahaman atau ideologi filsafat telah mengambil sebagian wilayah dari agama islam, sehingga kita sebagai muslim yang berpegang teguh kepada alQur'an dan Sunnah Rasulullah sallahu alaihi wasallama harus menyikapi hal tersebut dengan kritis. Apalagi doktrin yang diberikan liberalisme tidaklah sedkit yang mengaburkan keontentikan al-Qur'an dan hadits Nabi Muhammad sallalahu

\section{PEMBAHASAN}

\section{Islam Liberal (Liberalisme Islam)}

Pemahaman atau pemikiran liberalisme adalah satu istilah diantara istilahistilah untuk menyebut ideologi Dunia Barat yang berkembang sejak masa Reformasi Gereja yang mana menandakan berakhirnya abad pertengahan. Disebut dengan istilah liberal, secara harfiah mempunyai arti "bebas dari batasan” karena liberalisme menawarkan konsep kehidupan yang bebas dari aturan dan pengawasan geraja dan raja. ${ }^{4}$

Kata liberlisme barasal dari bahasa latin yaitu liber yang memiliki arti bebas atau merdeka, sampai mengujung abad 18 Masehi, kata ini sangat berkaitan erat dengan konsep manusia pada saat itu yang merdeka setelah dibebaskan

\footnotetext{
${ }^{3}$ Nashruddin Syarif, Menangkal Virus Islam Liberal, Panduan Islamic Worldview untuk Para Aktivis Dakwah (Bandung : Persis Pers, 2011), h,5.

${ }^{4}$ Ian Adams, Ideologi Politik Mutakhir, (Political Ideology Today, terj. Ali Noerz aman, (Yogyakarta : Qalam, 2004), 20.
} 
Volume 3, No. 12021

P-ISSN: 2655-5166

E-ISSN: $2715-2103$

Homepage : http://journal.iaimsinjai.ac.id/indeks.php/retorika

(budak). Oleh karena itu muncul lah istilah liberal arts yang artinya pengetahuan ini sangat berguna dan harus dimiliki oleh manusia yang merdeka. ${ }^{5}$

Islam liberal dilihat dari segi makna maka akan terlihat sangatlah kontradiktif, islam berasal dari bahasa arab yang artinya pasrah atau tunduk patuh sementara kata liberal berasal dari bahasa Eropa lebih tepatnya yunani yang artinya bebas. Disamping itu liberalisme dalam artian barat memiliki arti yang positif, akan tetapi jika dibawa ke dunia Timur terutama dunia Islam maka sudah terlanjur memilki konotasi yang buruk dan negatif. Ia lebih banyak difahami sebagai faham liarisme yang tidak mau tunduk kepada prinsip-prinsip, aturan-aturan, kaidah-kaidah apapun kecuali keliaran itu sendiri. Tetapi meskipun demikian jelas-jelas istilah tersebut sangat bertentangan atau memaksakan sehingga menjadikan sebagai satu istilah Islam liberal untuk dapat diterima dalam wacana dalam pemikiran islam. ${ }^{6}$

Para peneliti berbeda-beda dalam mendefiniskan Islam liberal, Charlez Kurzman memberikan karakter dasar dari apa yang disebut Islam liberal (Liberal Islam) sebagai berikut:

"Terdapat berbagai versi liberalisme Islam, tetapi satu elemen yang umum adalah kritiknya baik terhadap tradisi Islam adat maupun Islam revivalis, yang oleh kaum liberal disebut "keterbelakangan" (backwardness) yang, dalam pandangan mereka, menghalangi dunia Islam untuk menikmati "buah" modernitas: kemajuan ekonomi, demokrasi, hak-hak hukum, dan sebagainya. Di samping itu tradisi liberal berpendapat bahwa Islam, jika dipahami secara benar, sejalan dengan - atau bahkan perintis jalan bagiliberalisme barat.

Ada dua hal bagi Kurzman yang menjadi karakter dasar Islam liberal. Pertama, kritis terhadap tradisi Islam adat dan Islam Revivalis yang menyebabkan keterbelakangan umat Islam. Kedua, berkeinginan meraih kemajuan dengan mengedepankan nilai-nilai Islam yang ternyata sejalan dengan nilai-nilai liberalisme Barat seperti Demokrasi, kemajuan Ekonomi, hak-hak hukum dan

\footnotetext{
${ }^{5}$ Syamsuddin Arif, Orientalis dan Diabolisme Pemikiran, (Jakarta : Gema Insani, 2008), 76

${ }^{6}$ Dr. Anis Malik Thoha, Menangani Islam Liberal ; Pengalaman Indonesia dalam Islam Liberal Isu, Pneyelenggara Abdul Karim Ali, Mohd Roslan Mohd Nor, (Selangor : Penerbit Persatuan Ulama Malaysia, 2009), h.92.

7 Charlez Kurzman (ed.), Wacana Islam Liberal : Pemikiran Islam Kontemporer tentang Isu-isu Global, (Jakarta : Paramadina, 2003), h. xvii.
} 
Volume 3, No. 12021

P-ISSN: 2655-5166

E-ISSN: $2715-2103$

Homepage : http://journal.iaimsinjai.ac.id/indeks.php/retorika

sebagainya. Yang di maksud oleh Kurzman sebagai Islam Adat adalah kelompok Islam yang mengkombinasikan kebiasaan daerah dengan kebiasaan umum yang berlaku didunia Islam. ${ }^{8}$

Istilah ini sebanding dengan istilah "Islam Tradisional" yang populer lebih dahulu dikalangan para peneliti tentang gerakan islam di Indonesia seperti dalam karya klasik Deliar Noer. ${ }^{9}$ Sedangkan Islam revivalis ia sepadankan dengan Islamisme, Fudamentalisme, dan Wahabisme. Tradisi ini menyerang interpretasi adat yang kurang memberi perhatian tehadap inti doktrin islam.

Definisi ini hampir serupa dengan yang diberikan oleh Kamal Hassan, yaitu pokok pikiran yang mengikat berbagai pemikiran Islam liberal ini adalah selalu mendahulukan apa yang mereka sebut terhadap nilai-nilai Islam yang paling universal daripada formalitas praktik-prakti ajaran Islam. Niali-nilai ini secara sengaja atau tidak ternyata berkonsekuensi dengan nilai-nilai humanisme dan skularisme yang dipromosikan barat. ${ }^{10}$

Zuly qodir memberikan definisi yang lebih rigid terhadap Islam liberal, terutama dalam konteks Indonesia, yaitu mereka yang memiliki pemahaman inklusif terhadap Islam dengan ciri-crinya sebagai berikut:

“1) menempatkan al-Qur'an dan hadits sebagai kitab terbuka untuk diinterpretasikan tanpa harus terpaku pada satu bentuk intrpretasi yang sifat hegemonic, 2) melakukan rekonsiliasi antara keimanan dan modernitas, 3) bersedia mengadopsi sistem konstitusi dan kebudayaan dunia modern, 4) memiliki kebebasan dan menginterpretasi agama, 5) mengikuti pendidikan gaya modern dengan mengadopsi rasionalitas, 6) tidak berfikir sektarian sehingga dapat memahami perbedaan pandangan yang muncul tanpa melakukan penghakiman atas pihak lain yang berbeda, 7) mengakui adanya pluralisme agama, 8) bersifat inklusif-toleran dalam beragam, 9) berfikir dan bersifat terbuka melampaui batas-batas garis pemikiran organisasi keagamaan NU maupun Muhammadiyah, sekalipun banyak intelektual liberal di negeri ini yang berlatar belakang $N U$ dan Muhammadiyah, 10) tidak berminat pada gagasan pemberlakuan syariat Islam yang diformalisasi 11) memiliki teologi pluralis-inklusif, bukan eksklusif."

${ }^{8}$ Tiar Anwar Bachtiar, Pertarungan Pmeikiran Islam di Indonesia, (Jakarta : Pustaka Al-Kautsar, 2017), h.15.

${ }^{9}$ Deliar Noer, Gerakan Modern Islam di Indonesia 1900-1942, (Jakarta : LP3ES, 1993).

${ }^{10}$ Muhammad Kamal Hassan, Modernisasi Indonesia : Respon Cendikiawan Muslim, (Jakarta : Lingkaran Studi Indonesia, 1987), h.178.

${ }^{11}$ Zuly Qodir, Islam Liberal: Varian-varian Liberalisme Islam di Indonesia 1991-2002, (Yogyakarta : LkiS, 2010), h. 10. 
Volume 3, No. 12021

P-ISSN: 2655-5166

E-ISSN: 2715-2103

Homepage : http://journal.iaimsinjai.ac.id/indeks.php/retorika

Definisi yang disampaikan oleh Qodir memerinci lebih jelas mengenai identitas Islam liberal yang diajukan Kurzman dan Hassan. Melalui definisi ini, cukup jelas perbedaan gerakan Islam Liberal ini dengan gerakan modernisme Islam atau reformisme Islam sperti Muhammadiyah, Dewan Dakwah Islamiyah Indonesia, dan lainnya yang telah ada lebih dahulu.

\section{Sejarah Islam Liberal di Indonesia}

Kelahiran Islam liberal di Indonesia terbagi menjadi tiga fase yang berawal dari tahun 1970 kemudian berlangsung kepada pertumbuhan kedua dan perkembangannya setelah reformasi.

\section{Kelahiran Pemikiran Islam Liberal di Indonesia}

Periode kemunculan Islam liberal ini dimulai pada tahun 1970 an. Bila di berbagai belahan dunia lain seperti Mesir, India, Syiria dan beberapa negara Arab lainnya pemikiran ini lebih dahulu muncul, yaitu sekitar paruh waktu pertama abad 20, yang di Indonesia berbarengan dengan munculnya gerakan-gerakan Islam Modernis, maka di Indonesia pemikiran Islam liberal ini baru muncul pada tahun 1970-an ini.

Ada dua alasan yang dapat kita simpulkan mengapa di Indonesia muncul lebih belakangan. Pertama, sejak lama tradisi pemikiran di Indoneisa masi belum menampakkan tradisi sebagai "produsen" pemikiran, melainkan hanya sebagai "konsumen". Umat Islam di Indonesia lebih bersifat sebagai penerima apa yang telah berkembang di dunia luar, terutama Timur Tengah, yang dianggap sebagai pusat kekuatan dan penyebaran Islam. belum banyak pemikiran-pemikiran Islam asli Indonesia yang disebarluaskan ke Timur tengah. Kasus terjadi sebaliknya. Karena itu, apabila tokoh-tokoh Indonesia yang memiliki pengaruh luas di dunia Islam, ia harus bersentuhan dengan Timur Tengah, seperti para ulama yang berkarir dan terkenal di Timur Tengah, seperti Syekh Nawawi Al-Bantani, Syekh Mahfuz Termasi, Syekh Yusuf Al-Makassari, Syekh Ahmad Khatib Minangkabau, dan Syekh Abdul Shamad Palembang. ${ }^{12}$

${ }^{12}$ Penjelasan tentang ulama-ulama Nusantara yang berkarir di Timur Tengah dan dapat pengaru cukup besar dapat dilihat dalam buku-buku yang menerangkan biografi ulama-ulama tersebur. 
Volume 3, No. 12021

P-ISSN: 2655-5166

E-ISSN: 2715-2103

Homepage : http://journal.iaimsinjai.ac.id/indeks.php/retorika

Kedua, tahun 1970-an baru baru dimungkinkan munculnya pemikiran Islam liberal ini karena pada tahun-tahun inilah intelektual Islam yang mendapat pengaruh pemikiran Islam liberal dari Timur Tengah mulai muncul seperti Harun Nasution dan Abdurrahman Wahid. Dalam konteks ini keduanya mendpatkan banyak pengaruh dari pemikir-pemikir Islam liberal di Mesir. Tokoh-tokoh yang mengambil ilmu di Mesir sebelum kedua orang ini seperti Mahmud Junus, Abdul Kahar Muzakkir, M. Rasjidi, dan lainnya tidak terpengaruh dengan pemikiran Islam liberal. Mereka malah tercatat sebagai pembela sistem dan kurikulum Universita Al-Azhar yang dinilai oleh para pemikir liberal Mesir sebagai orangorang yang kolot dan terbelakang. ${ }^{13}$ Harun Nasution dan Abdurrahman Wahid yang memeilki pengaruh paling mendalam dalam penyebaran pemahaman Islam liberal di Indonesia, Harun Nasution sangat berperan dalam penyebaran Islam liberal di IAIN, sedangkan Abdurrahman Wahid memiliki pengaru yang besar di Nahdhatul Ulama (NU). ${ }^{14}$

Pemikiran Islam liberal pada umumnya selalu dikaitkan dengan Nurchalis Madjid. Perstiwa pertama yang mengaitkan Islam liberal dengan Nurchalis Madjid yang digadang sebagai pencetus Islam liberal adalah pidatonya pada acara silaturahmi Idhul Fithri pada tanggal 3 Januari 1970,dan diikuti oleh berbagai macam ormas-ormas Isalm. Dalam pidatonya Madjid menyampaikan tentang keadaan umat Islam yang jumud (mendek) akibat terus menerus mengulang keinginan memperjuangkan berdirinya kembali negara Islam melalui partai-partai. Madzjid mengusulkan satu jargon yang kontrovesrsial "Islam Yes, Partai Islam No!" ia juga mengatakan umat Islam perlu melakukan "sekularisasi” pemikiran, berpikir bebas dan terbuka. Untuk itu pula diperlukan kelompok pembaharuan yang "liberal". 15

\footnotetext{
${ }^{13}$ Mona Abaza, Pnedidikan Islam dan Pergeseran Orientasi : Studi Kasus Alumni AlAzhar (terj), (Jakarta : LP3ES, 1999), h. 66-85.

${ }^{14}$ YudiLatif, Intelegensia Muslim dan Kuasa : Genealogi Integensia Muslim Indonesia Abad ke-20, hlm. 524-525.

15 Nurchalis Madjid, Islam, Kemodernan, dan Keindonesiaan, (bandung : Mizab Pustaka), h. 247-259.
} 
Volume 3, No. 12021

P-ISSN: 2655-5166

E-ISSN: 2715-2103

Homepage : http://journal.iaimsinjai.ac.id/indeks.php/retorika

2. Pertumbuhan Generasi Kedua

Setelah pemikiran-pemikiran yang berhaluan Islam liberal mucul ke publik, baik melalui tulisan-tulisan Nurchalis Madjid di media masa maupun kurikulum di IAIN, maka perkembangannya menjadi semakan pesat dan meluas. Semakin banyak orang yang bergerak di belakang ide-ide pembaharuan Nurchalis Madjid dan ide-ide rasionalnya Harun Nasution mengindikasikan bahwa pengaruh itu terus meluas, sekalipun kadar pengaruh pada orang-orang yang menerimanya sangat mungkin tidak sama dan sulit juga dilakukan penguuran secara pasti. Namun yang pasti, pemikiran Islam liberal yang dicetuskan itu tidak berhenti sampai pada pelemparan wacana.

Ada banyak sekali faktor yang mendukung semakin berkembangnya pemikiran Islam liberal ini diantarnya: terlibat intelektual-intelektual Islam liberal ini di berbagai lembaga kaderisasi intelektual seperti organuisasi kemahasiswaan dan perguruan tinggi, juga berbagai orams Islam seperti NU dan Muhammadiyah. Selai itu, faktor dukungan dari pemerintah yang memasilitasi berkembangnya model pemikiran ini juga turut memperkuat tersebarnya pemikiran Islam liberal. Juga tersebarnya ide-ide yang menjadikan pemikiran ini tersebar sehingga memungkinkan pemikiran Islam liberal ini menjadi salah satu pemikiran yang dapat di apresiasi dari berbagai kalangan, gagasan dan ide yang di sampaiukan Nurchalis Madjid sangatlah banyak dan dia berikan kepada kaderisasi HMI, disamping itu juga Abdurraman Wahid sangat berperan dalam memberikan ideideya seperti, mengajak kepada Pluralisme Agama, pribumisasi Islam, kesetaraan gender dll. ${ }^{16}$

3. Islam Liberal Setelah Reformasi

Seiring terbukanya kran kebebasan berpendapat dan menyampaikan gagasan, dalam konteks sejarah pemikiran Isalam pu terjadi perubahan yang cukup penting, sekalipun petanya masi belum beranjak dari peta lama yang muncul sejak zaman orde baru. Pada masa orde baru polarisasi pemikiran Islam

${ }^{16}$ Tiar Anwar Bachtiar, Pertarungan Pmeikiran Islam di Indonesia, (Jakarta : Pustaka Al-Kautsar, 2017), h. 57-70. 
Volume 3, No. 12021

P-ISSN: 2655-5166

E-ISSN: $2715-2103$

Homepage : http://journal.iaimsinjai.ac.id/indeks.php/retorika

antara kelompok "tradisionalis" dan "modernis"17 yang menjadi poros pemikiran utama pada paruh pertama abada ke 20 sedikit demi sedikit bergeser dengan munculnya satu varian pemikiran baru yang dalam penelitian ini disebut sebagai "Islam Liberal". Eksponennya terdiri dari intelektual-intelektual yang sebelumnya cenderung kepada kelompok "tradisionalis" seperti Abdurrahman Wahid dan Nurchalis Madjid dari kalangan NU, dan sebgaian lain kepada kelompok "modernis" seperti Harun Nasution dan Munawir Sajdzali yang dibesarkan dalam tradisi Muhammadiyah.

Munculnya kelompok Islam liberal ini tidak menghentikan polarisasi, hanya menggeser plarisasi dari tradisionalis-modernis ke polarisasi lain, yaitu polarisasi kelompok Islam liberal dengan pengkritiknya. Beberapa peneliti barat menyebut kelompok anti-Islam liberal ini sebgai kelompok "fundamentalis", "konservatid", dan ada pula yang menyebut sebagai kelompok dakwah. ${ }^{18}$

Sebagaimana kelompok Islam liberal, pendukung anti-Islam liberal pun sama-sama berasal dari kelompok tradisionalis maupun modernis. Peristiwa paling mencolok adalah dukungan NU dan Muhammadiyah secara institusi atas fatwa haram pemikiran skularisme, pluralisme, dan liberalisme pada mukhtamar masing-masing 2004-2005. Kemudian dukungan ini bergulir sampai fatwa MUI tahun 2005 yang para tokoh-tokohnya berasal dari dua organisasi terbesar wakil kelompok tradisionalis dan modernis tersebut. Penentang fatwa MUI tahun 2005 inipun muncul dari kalangan NU dan Muhammadiyah seperti dari Abdurrahman Wahid (NU) dan Abdul Munir Mulkhan (Muhammadiyah). ${ }^{19}$

Kebebasan menyampaikan pendapat pada Era Reformasi ini dimanfaatkan secara antusias oleh para intelektual Islam liberal. Sejak orde baru mereka sebetulnya sudah berani menyampaikan pemikiran-pemikiran meraka ke publik, namun saat ini, mereka semakin berani. Bahkan mereka dengan sangat terbuka menyatakan haluan pemikiran mainstream mereka, yaitu "liberal". Momen sejarah

${ }^{17}$ Mengenai varian ini bisa dilihat secara lengkap dan dijelaskan oleh Deliar Noer, Gerakan Modern Islam di Indonesia 1900-1942, (Jakarta: LP3ES, 1993).

${ }^{18}$ Tiar Anwar Bachtiar, Op, Cit, h. 87.

${ }^{19}$ Ibid. 
Volume 3, No. 12021

P-ISSN: 2655-5166

E-ISSN: 2715-2103

Homepage : http://journal.iaimsinjai.ac.id/indeks.php/retorika

yang menandai keberanian mereka tampil di publik secara vulgar adalah pada saat didirikannya Jaringan Islam Liberal (JIL) di Jakarta pada tahun 2001.

Ahmad Ali Nurdin menyebut lahirnya JIL ini sebagai respon terhadap berdirinya organisasi-organisasi Islam yang disebut sebgaai fundamentalisradikal seperti MMI (Majelis Mujahidin Indonesia), FPI (Front Pembela Islam), Laskar Jihad, HTI (Hizbut Tahrir Indonesia), KISDI (Komite Islam untuk Solidaritas Dunia Islam). ${ }^{20}$

\section{Ktitik dan Respon Terhadap Pemikiran Islam Liberal Setelah Reformasi}

Kebebasan berpendapat pada periode ini menjadi salah satu kata kunci yang membedakan tanggapan-tanggapan terhadap pemikiran Islam liberal pada periode ini dengan periode sebelumnya pada masa Orde Baru yang sangat membatasi kebebasan pers dan mengemukakan pendapat. Keinginan dan semangat umat Islam untuk menjalankan agamnya secara sempurna tidka lagi disampaikan secara sembunyi. Umat muslim semakin berani menyuarakan keinginan mereka untuk menerapkan syariat Islam secara sempurna (kaffah) di Indonesia, termasuk dalam bidang politik dan negara.

Oleh karena itu, bemuculanlah berbagai macam organisasi dan gerakan yang memiliki tujuan menegakkan Islam secara sempurna tidak bisa dibendung lagi. Bahkan, mereka sudah berani mendirikan partai-partai politik Islam yang memiliki visi mis menegakkan syariat agama Islam dalam sistem politik Indonesia ini. Dengan semangat itulah muncul lah ormas-ormas Islam seperti FPI (Front Pembela Islam), MMI (Majelis Mujahidin Indonesia), KPPSI (Komita Pengkajian dan Penegakkan Syariat Islam), HTI (hizbut Tahrir Indonesia), dan lainnya. Selain itu juga lahir partai-partai politik Islam seperti PBB (Partai Bulan Bintang), PKS (Partai Keadilan Sejahtera), dan lainnya, semua itu bertujuan untuk menegakkan syariat Islam di Indonesia tercinta ini.

Berikut ini akan kami paparkan sedikit mengenai kritik balik terhadap pemikiran Isalm liberal setelah jatuhnya Soeharto setelah tahun 1998 atau setelah reformasi.

20 Ahmad Ali Nur, Islam and State: A Study of The Liberal Islamic Network in Indonesia 1999-2004 dalam New Zeland Jurnal of Asian Studies 7,2 (Desember, 2005),h. 21-23. 
Volume 3, No. 12021

P-ISSN: 2655-5166

E-ISSN: $2715-2103$

Homepage : http://journal.iaimsinjai.ac.id/indeks.php/retorika

1. Kritik Para Penulis Lepas

Diantara penulis terkenal pada masa ini yang mengkritik Islam liberal adalah Hartono Ahmad Jaiz ${ }^{21}$ yang aktif menjadi peneliti Lmbaga Peneliti dan Pengkajian Islam (LPPI) pimpinan Amin Djamaludin. Jaiz dikenal sebagai penulis yang selalu menyampaikan pandngan-pandangannya tanpa berfikir akibat dari itu bisa disebut tanpa pandang bulu. Ia bahkan tidak segan-segan menggunakan katakata yang tegas dan keras kepada sasaran krtiknya.

Tahun 1997, ia sempat menerbitkan buku berjudul Rukun Iman Digoncang. Buku ini hanya memeliki 75 halaman. Isinya adalah kumpulan artikel, hasil liputan dan wawancara untuk mengkritik Harun Nasution tentang iman kepada takdir (qadha dan qadar). Argumentasinya memang tidak begitu mendalamakan tetapi menghadirkan kesan bahaya dari pemikiran Harun Nasution ini ia memilih judul yang sarkastis. Dengan judul itu Jaiz seolah ingin menggambarkan bahwa betapa bahayanya pemikiran Harun Nasution hingga dapat mengguncang keimanan seseorang. Dan di dalalmnya termuat pandangan dari beberapa tokoh seperti Ali Yafie, Peunoh Dalih (IAIN), A. Latif Muchtar (Persisi), Ali Halabi (al-Isryad), Rasjidi dan lainnya yang bersebrangan dengan pendapat Harun Nasution.

Penulis yang lain bergerak secara pribadi adalah Agus Hasan Bashori. Ia adalah seorang lulusan LIPIA (Lembaga Ilmu Pengetahuan Islam dan Arab) Jakarta, tempat Ulil Abshar Abdallah pernah singgah disana menimbah ilmu. Bashori pernah satu priode dengan Ulil di LIPIA Jakarta. Bisa jadi perhatian Bashori terhadap masalah-masalah Islam liberal juga dipicu oleh perkenalan dengan Ulil di LIPIA. Padahal, walaupun hampir semua lulusan lembaga ini tidak setuju dengan pemikiran Islam liberal namun tidakbanyak yang mengkritik dan menulis dengan tema ini. Di antara tidakbanyak itu adalah Agus Hasan Bashori ini. Setidaknya dia menulis dua buku untuk topik ini : Mewaspadai Gerakan Kontekstualisasi Al-Qur'an; Menanggapi Ulil Abshar Abdalla (2003), Koreksi

\footnotetext{
${ }^{21}$ Hartono Ahmad Jaiz adalah wartawan yang juga salah seorang kader DDII. Ia pernah menjadi penulis tetap di Majalah Media Dakwah, kritik-kritiknya terhadap gejala Islam liberal baru dipelopori Ulil Abshar Abdalla, melahirkan buku-buku: Mengkritisi Debat Fikih Lintas Agama (2004), Aliran-aliran sesat di Indonesia (2006).
} 
Volume 3, No. 12021

P-ISSN: 2655-5166

E-ISSN: $2715-2103$

Homepage : http://journal.iaimsinjai.ac.id/indeks.php/retorika

Total Buku Kintas Agama; Membongkar Kepalsuan Paham Pluralis-Inklusif (2004). Kdua buku inidiberi kata pengantar oleh Hartono Ahmad Jaiz yang menandaka ${ }^{22} \mathrm{n}$ bahwa ikon anti pemikiran Islam liberal pada masa itu adalah Ahrtono Ahmad Jaiz.

Walaupun diberikan pengan oleh Hartono Ahmad Jaiz yang gayanya sering ke arang sarkastis, tetapi tuliasn Bashori lebih dingin dan gaya argumennya sama dengan buku yang ditulis oleh Ahmad Husnan dan Daud Rasyid, yaitu banyak menampilkan argumen Al-Qur'an dan hadits-hadits Nabi salallahu alahi wasallam, untuk menolak pemikiran-pemikiran Islam liberal, terutama tulisan Ulil Abshar dan buku FLA.

\section{FUUI dan MMI}

Selain mendapatkan tanggapan dari individual, selain pemikiran Islam liberal pun mendapat tanggapan dari kelompok gerakan dan ormas islam. Tanggapan ini terutama stelah muncul tulisan Ulil di Kompas. Diantara tanggapan kelompok yang paling keras dilontarkan oleh Forum Ulama Umat Indonesia (FUUI). Pada tanggal 30 November 2002, FUUI mengundang sejumlah tokoh dan ulama di Jawa Barat. Mereka berkumpul di Masjid Al-Fajr, Buah Batu, Bandung, markas FUUI. Dalam pertemuan itu dibahas secara khusus menganai JIL dan tulisan Ulil di Kompas. Dia antara butir pernyataan FUUI sebagai rekomendasi dari pertemuan tersebut adalah:

"Menuntut aparat penegak hukum untuk membongkar jaringan dan kegiatan yang secara sistematis dan masif melakukan penghinaan terhadap Allah, Rasulullah, umat Islam dan para ulama" "Menurut Syari'at Islam, oknum yang menghina dan memutarbalikan kebenaran agama dapat diancam dengan hukuman mati",23

Selain FUUI yang bersikap keras terhadap JIL, ormas yang baru didirikan oleh KH. Abu Bakar Ba'asyir, yaitu Majelis Mujahidin Indonesia (MMI) juga bereaksi cukup keras. Reaksi pertama muncul ketika JIL beriklan di televisi dengan tema pluralisme agama pada sekita bulan Mei-Juli 2002. Iklannya sendiri dinamai "Islam Warna Warni”. MMI yang diawakili oleh ketua Departemen Data dan Informasi Majelis Mujahidin Indonesia, Fauzan Al-Anshari, menyampaikan

${ }^{22}$ Tiar Anwar Bachtiar, Op, Cit, h.143

${ }^{23}$ Ibid, h. 145 
Volume 3, No. 12021

P-ISSN: 2655-5166

E-ISSN: $2715-2103$

Homepage : http://journal.iaimsinjai.ac.id/indeks.php/retorika

Somasi kepada RCTI dan SCTV, pada tanggal 4 Agustus 2002. Karena menanykan Islam Warna Warni dai JIL. Iklan itu pun dibatalkan. Kubu utan kayu membalas dengan melaporkan Fauzan ke polisi. ${ }^{24}$

3. Muktamar NU dan Muhammadiyah

Hiruk pikuk yang tengah memanas menganai pemikiran Islam liberal ini ternyata sampai juga kepada dua ormas terbesar di indonesia yaitu Nahdhatul Ulama dan Muhammadiyah. Bukan hanya sampai, tapi benar-benar berimbas pada kebijakan dua organisasi tersebut. Kebijakan yang diambil oleh $\mathrm{Nu}$ dan Muhammadiyah melalui Muktamar masing-masing yang merupakan forum pengambilan kebijakan tertinggi dari kedua ormas ini membukakkan jalan lurus lahirnya fatwa MUI kemudian.

Beberapa petinggi $\mathrm{Nu}$ saat itu sebetulnya tidak bersikap terlalu tegas terhadap fenomena Islam liberal ini. Hasyim Muzadi, ketua PBNU saat itu, tidak terlalu khawatir denga kemunculan JIL di indonesia. Hanya saja, mereka perlu mendapatkan bimbingan agar tidak sampai menyimpang dari agam Islam. Sebelum menyampaikan pendapat ada baiknya mereka mendiskusikannya terlebih dahulu secara mendalam sehingga tidak timbul gejolak ditengah masyarakat. ${ }^{25}$ Beberapa petinggi NU malah mendukung pemikiran Ulil dan kawan-kawan seperti Abdurrahman Wahid, Said Agil Siraj. Mereka bahkan dikenal sebagai tauladan dan mentor bagi anak-anak muda.

Walaupun ada sebagian suara-suara petinggi NU yang menganggap biasa saja, bahkan positif, terhadap gerakan Islam liberal ini, namun memansanya polemik mengenai Islam liberal setelah reformasi hingga tahun 2005 ikut memantik api ke tengah organisasi NU ini. Kegerahan terhadap Islam liberal ini bermula dari beberapa kiai NU di Jawa Timur yang merasah resah dengan anakanak muda $\mathrm{Nu}$ yang terlibat mendirikan mendirikan JIL. Keresahan ini tertuang secara resmi saat diselenggarakan Konferensi Wilayah NU 11-13 Oktober 2002 yang salah satu Tausiahnya dari Konwil ini menolak pemikiran Islam liberal ini. Konwil mengamanatkan sebgai berikut:

\footnotetext{
${ }^{24} \mathrm{http}$ ///wordpress.com/anti-pemurtadan/mengenal-aliran-sesat-jaringan-islam-liberal/

${ }^{25}$ Muhammad Ali, The Rise The Liberal Islam Network (JIL) in Contemporary Indonesia, dalam The American Jurnal of Islamic Social Sciences, t.t, h. 18.
} 
Volume 3, No. 12021

P-ISSN: 2655-5166

E-ISSN: $2715-2103$

Homepage : http://journal.iaimsinjai.ac.id/indeks.php/retorika

"Kepada PBNU Jawa Timur agar segera menginstuksikan kepada warga $N U$ mewaspadai dan mencegah pemikiran Islam liberal dalam masyarakat. Apabila pemikiran Islam liberal dimunculkan oleh para pengurus $N U$ (disemua tingkatan) diharapkan ada sangsi, baik berupa teguran keras maupun sanksi organisasi (sekalipiun dianulir dari kepengurusan)."26

Bila NU, nasib pemikiran Islam liberal berujung ke Muktamar, maka di Muhammadiyah pun sama. Ahmad Najib menengarai bahwa pertarungan kubu Islam liberal (Najib: Islam progresif) dan tidak menuyetujuinya (Najib: Islam murni) sudah terjadi sejak Muktamar tahun 1995 di Banda Aceh. ${ }^{27}$ Terpilihnya Amin Rais yang memiliki kedekatan dengan beberapa aktivis Islam liberal memberika peluang kepada dua orang tokoh yang di anggap liberal, yaitu M.Amir Abdullah dan Abdul Munir Mulkhan untuk duduk di jajaran PP Muhammadiyah. Andullah yang dipercayai menjadi ketua Majelis Tarjih dan Pengembangan Pemikiran Islam (MTPPI) menggagas program-program yang berorietasi pada pemikiran Islam liberal. Misalnya ia memulai memperkenalkan penafsiran dengan pendekatan hermeneutika. Ia menerbitkan buku berjudul Tafsir Tematik AlQur'an yang merupakan kumpulan karangan dari beberapa aktivis Muhammadiyah yang cenderung pemikiran Islam liberal. Terbitnya buku ni mulai menimbulkan kontroversi di kalangan anggota Muhammadiyah,.

Puncak "pegadilan" terhadap Islam liberal Muhammdiyah terjadi pada Muktamar ke 45 di malang 3-8 Juli 2005. Kencangnya arus perlawanan terhadap kubu liberal di Muhammadiya mendorong majalah Tabligh mendirikan stan khusus selama Muktamar berlangsung dan dinamai "Pojok Anti Liberal". Stan ini menjual pernak-pernik, DVD, kaos, majalah, buku-buku, dan yang laiinya yang bernuansa penolakan terhadap Islam liberal. Selembaran juga dibagikan untuk mengantisipasi terpilihnya tokoh-tokoh liberal menjadi pemimpin Muhammadiyah. Stan ini pun mengadak diskusi dengan topi "Islam Liberal" yang tujuannya untuk menyadarkan para peserta Muktamar dari bahayanya Islam Liberal.

\footnotetext{
${ }^{26} \mathrm{http}$ ///wordpress.com/anti-pemurtadan/mengenal-aliran-sesat-jaringan-islam-liberal/

${ }^{27}$ Ahmad Najib dalam Bruinessen (ed.), 2014,hlm. 162-174.
} 
Volume 3, No. 12021

P-ISSN: 2655-5166

E-ISSN: 2715-2103

Homepage : http://journal.iaimsinjai.ac.id/indeks.php/retorika

4. Fatwa Majelis Ulama Indonesia (MUI)

Seperti tongkat estafet, ramainya perbincangan mengenai pemikiranpemikiran Islam liberal hingga sampai di muktamar dua ormas terbesar di Indonesia, NU dan Muhammdiyah, akhirnya sampai juga di meja Mejlelis Ulama Indonesia yang semenjak Era Rofrmasi cukup menjadi mempresentasi umat Islam. Secara kebetulan, MUI juga melaksanakan Musyawarah Nasionalnya pada 26-29 Juli 2005, tidak lama berselang dari Muktamar NU dan Muktamar Muhammadiyah. Pada Musnahnya kali ini dibahas pula secara khusus mengenai pamikiran-pemikiran yang digagas oleh kelompok Islam liberal di samping isu-isu lain yang tidak terlalu banyak mendapat perhatian publik.

Pembahasan Komisi Fatwa atas pemikiran Islam liberal akhirnya berujung pada terbitnya Fatwa MUI no.7/MUNAS VII/MUI/11/2005 tentang Pluralisme, Liberalisme, dan Sekularisme Agama. Oleh sebagian kalangan kata "Pluralisme, Liberalisme, dan Sekularisem" ini dibuat akronimnya denga sebutan "Sepilis" (sekularisme,liberalisme, dan pluralisme). Istilah ini terutama dibuat oleh kelompok anti-Islam liberal dengan nada penghinaan seolah-olah pemikiran ini sama dengan salah satu jenis penyakit kelamin.

Draft konsideran fatwa Majelis Ulama Indonesia (MUI) lampiran sebagai berikut :

1) Pluralisme, Sekularisme, dan Liberalisme agama sebagaimana dimaksud pada bagian pertama adalah paham yang bertentangan dengan ajran agama islam.

2) Umat Islam haram mengikuti paham Pluralisme, Sekularisme dan Liberalisme agama.

3) Dalam masalah aqidah dan ibadah, umat Islam wajib bersikap ekslusif, dalam arti haram mencampuradukkan aqidah dan ibadah umat Islam dengan aqidah dan ibadah pemeluk agama lain.

4) Bagi masyarakat muslim yang tinggal bersama pemeluk agama lain (pluralisme agama), dalam masalah sosial yang tidak berkaitan dengan aqidah 
Volume 3, No. 12021

P-ISSN: 2655-5166

E-ISSN: 2715-2103

Homepage : http://journal.iaimsinjai.ac.id/indeks.php/retorika

dan ibadah, umat Islam bersikap inklusif, dalam arti tetap melakukan pergaulan sosial dengan agama lain sepanjang tidak saling merugikan. ${ }^{28}$

\section{Tokoh-tokoh dan Buku-buku Pengusung Paham Liberalisme dan}

\section{Penentangnya}

a. Tokoh-tokoh Pengusung Paham Liberalisme

$>$ Harun Nasution

$>$ Munawir Sadzali

$>$ Nurcholis Majid

$>$ Abdurrahman Wahid

$>$ Ulil Abshar Abdalla

$>$ Budi Munawar Rachman

b. Buku-buku pengusung paham Islam Liberal

- Refleksi Pembaharuan Pemikiran Islam - Harun Nasution

- Kontekstualisasi Ajaran Islam - Munawir Sadzali

- Fiqih Lintas Agama - Nurchalis Madjid

- Islam Doktrin dan Peradaban - Nurchalis Madjid

- Menyegarkan Kembali Pemikiran Islam - Ulil Abshar Abdalla

- Pintu-pintu Menuju Tuhan - Nurchalis Madjid

c. Tokoh-tokoh Penentang Paham Islam Liberal

$>$ Ahmad Husnan

$>$ H.M. Rasjidi

Syed M. Naquib Al-Attas

$>$ Daud Rasyid

$>$ Hamid Fahmi Zarkasyi

Adian Husaini

\footnotetext{
${ }^{28} \mathrm{http}$ ://mui.or.id/wp-content/uploads/2014/05/12b.-Penjelasan-Tentang-Fatwa-PluralismeLiberalisme-dan-Se.pdf (diunduh 12 Agustus 2014).
} 
Volume 3, No. 12021

P-ISSN: 2655-5166

E-ISSN: 2715-2103

Homepage : http://journal.iaimsinjai.ac.id/indeks.php/retorika

\section{KESIMPULAN}

Islam liberal atau bisa dikatakan liberalisme Islam merupakan salah satu pemikiran yang sangat bertentangan dengan prinsip-prinsip Islam. Melihat dari istilahnya saja sudah sangatlah jauh dan kontradiksi, yang mana Islam artinya adalah menyerah atau tunduk dan patuh kepada Allah ta'ala dan aturan-aturan agama sedangkan liber memiliki arti bebas yang memliki arti boleh berpahaman bebas dalam konteks keislaman.

Dalam perkembangan Islam liberal di indonesia dikatakan oleh para pakar bahwa pemikiran Islam liberal pertama muncul pada tahun 1970 M, yang dibawakan oleh para intelektual Islam yaitu Nurchalis Madjid, Abdurahman Wahid dll, berlangsung perumbuhannya pada pertumbuhan kedua yang mana pemikiran-pemikiran dari kalangan Islam liberal tersebar dalam kampus-kamous dan buku-buku yang dikarang oleh mereka dan ketiga yaitu pada masa setelah reformasi, yang mana pada masa ini terjadi perdebatan hingga MUI melarang akan pemikiran Islam liberal.

Stelah reformasi atau setelah jatuhnya pemerintahan Suharto, masyarakat Indonesia mulai bisa keluar dari keterpurukan dan bisa menyampaikan pemikiranpemikran mereka di majalah dll, dari sini banyak sekali pengkritik dari kalangan penulis umum terhadap pemikiran Islam liberal, dan datang juga dari berbagai organisasi masyarakat seperti NU dan Muhammadiyah. Setelah dua organisasi besar tersebut mengkritik pemikiran Liberal, MUI mengeluarkan fatwa tentang pelarangan pemikiran pluralisme, liberalisme dan skularisme pada tahun 2005.

\section{DAFTAR PUSTAKA}

Ahmad Ali Nur, Islam and State: A Study of The Liberal Islamic Network in Indonesia 1999-2004 dalam New Zeland Jurnal of Asian Studies 7,2 (Desember, 2005)

Charlez Kurzman (ed.), Wacana Islam Liberal : Pemikiran Islam Kontemporer tentang Isu-isu Global, (Jakarta : Paramadina, 2003)

Deliar Noer, Gerakan Modern Islam di Indonesia 1900-1942, (Jakarta : LP3ES, 1993) 
Volume 3, No. 12021

P-ISSN: 2655-5166

E-ISSN: $2715-2103$

Homepage : http://journal.iaimsinjai.ac.id/indeks.php/retorika

Dr. Anis Malik Thoha, Menangani Islam Liberal ; Pengalaman Indonesia dalam Islam Liberal Isu, Pneyelenggara Abdul Karim Ali, Mohd Roslan Mohd Nor, (Selangor : Penerbit Persatuan Ulama Malaysia, 2009)

Ian Adams, Ideologi Politik Mutakhir, (Political Ideology Today, terj. Ali Noerz aman, (Yogyakarta : Qalam, 2004)

Muhammad Ali, The Rise The Liberal Islam Network (JIL) in Contemporary Indonesia, dalam The American Jurnal of Islamic Social Sciences

Muhammad Hamid An-Nashir, Mengupas Hakikat Gerakan Modernisasi, liberalisme dan Westernisasi Ajaran islam, (Darul Haq : Jakarta, 2016)

Muhammad Kamal Hassan, Modernisasi Indonesia : Respon Cendikiawan Muslim, (Jakarta : Lingkaran Studi Indonesia, 1987)

Mona Abaza, Pnedidikan Islam dan Pergeseran Orientasi : Studi Kasus Alumni AlAzhar (terj), (Jakarta : LP3ES, 1999)

Nirwan Syarifin, Kritik Terhadap Paham Liberalisasi Syariat Islam (Jakarta : Dewan Dakwah Islamiyah Indonesia, 2008)

Nashruddin Syarif, Menangkal Virus Islam Liberal, Panduan Islamic Worldview untuk Para Aktivis Dakwah (Bandung : Persis Pers, 2011)

Nurchalis Madjid, Islam, Kemodernan, dan Keindonesiaan, (bandung : Mizab Pustaka)

Syamsuddin Arif, Orientalis dan Diabolisme Pemikiran, (Jakarta : Gema Insani, 2008)

Tiar Anwar Bachtiar, Pertarungan Pmeikiran Islam di Indonesia, (Jakarta : Pustaka Al-Kautsar, 2017)

YudiLatif, Intelegensia Muslim dan Kuasa : Genealogi Integensia Muslim Indonesia Abad ke-20.

Zuly Qodir, Islam Liberal: Varian-varian Liberalisme Islam di Indonesia 19912002, (Yogyakarta : LkiS, 2010)

http://wordpress.com/anti-pemurtadan/mengenal-aliran-sesat-jaringan-islam$\underline{\text { liberal/ }}$

http://mui.or.id/wp-content/uploads/2014/05/12b.-Penjelasan-Tentang-FatwaPluralisme-Liberalisme-dan-Se.pdf (diunduh 12 Agustus 2014). 